\title{
Serum copper and related variables in rheumatoid arthritis
}

\author{
P. R. SCUDDER, D. AL-TIMIMI, W. McMURRAY, A. G. White, \\ B. C. ZOOB, AND T. L. DORMANDY
}

From the Departments of Clinical Pathology and Rheumatology, Whittington Hospital, and Department of Rheumatology, University College Hospital, London

SUMMARY Serum copper, caeruloplasmin, iron, iron-binding capacity, and antioxidant activity were measured in 120 normal subjects and in 189 patients with rheumatoid arthritis. Both serum copper and serum caeruloplasmin were significantly raised in rheumatoid disease in both sexes. A significant inverse relation was found between serum iron and serum copper, and a strong direct correlation between serum antioxidant activity and caeruloplasmin.

Much evidence points to an abnormal copper metabolism in rheumatoid disease (reviewed by Scudder, 1976) and in related disorders (Jayson et al., 1976) but reports on serum copper levels have been confusing and contradictory (Koskelo et al., 1966; Bajpayee, 1975). There has also been uncertainty about the relation of serum copper and caeruloplasmin (Lorber et al., 1968; Sternlieb et al., 1969; Scudder, 1976). We report our findings in several groups of patients with rheumatoid arthritis (RA) receiving different forms of treatment, together with appropriate groups of control subjects.

\section{Subjects}

A total of 120 normal control subjects and 189 patients with clinically established RA were studied. The severity, extent, and activity of the disease varied. A series of 100 patients ('main rheumatoid group') treated with analgesic/anti-inflammatory drugs only (salicylates 3-4 g/day; indomethacin $50-200 \mathrm{mg} /$ day; ibuprofen 0.8-1.6 g/day; phenylbutazone $300 \mathrm{mg}$ /day) was compared with an age- and sex-matched group of healthy controls. The RA group consisted of 60 females with a mean $( \pm S D)$ age of $54 \cdot 6 \pm 13.2$ years and 40 males with a mean age of $55.5 \pm 14.4$ years. The control group consisted of 60 females with a mean age of $51.4 \pm 15.8$ years and 40 males with a mean age of $52.0 \pm 13.2$

Accepted for publication May 10, 1977

Correspondence to Dr T. L. Dormandy, Department of Chemical Pathology, Whittington Hospital, Archway Wing, Archway Road, London N19 3UA years. None of the women in these groups was taking oral contraceptives. The remaining RA patients and controls were divided into subgroups: 20 female control subjects receiving oestrogen-based oral contraceptives; 25 female RA patients being treated with either intra-articular corticosteroids or intramuscular ACTH; 44 RA patients (30 females, 14 males) receiving intramuscular sodium aurothiomalate (Myocrisin) (total dosage range 0.5 g-5.0 g); and 20 RA patients who had been receiving oral D-penicillamine for 6 months.

\section{Method}

\section{SERUM COPPER}

Copper was measured with a Perkin Elmer Model 306 atomic absorption spectrophotometer (Perkin Elmer, Beaconsfield, Bucks.). Protein-free extracts were prepared by diluting serum with 1 volume of $200 \mathrm{~g} / \mathrm{l}$ trichloroacetic acid, followed by mixing and centrifugation. The supernatants were aspirated directly into an air/acetylene flame.

\section{SERUM GOLD}

Gold was also measured by atomic absorption spectrophotometry. To improve sensitivity a digestion/extraction technique was used (Balazs et al., 1972).

\section{CAERULOPLASMIN}

Caeruloplasmin was estimated by single radial immunodiffusion (Mancini et al., 1965). Commercially prepared M-Partigen immunodiffusion plates and lyophilized protein standards were 
obtained from Hoechst Pharmaceuticals, Hounslow, Middx.

\section{SERUM IRON}

Iron and total iron-binding capacity were determined by a standard autoanalyser method (Young and Hicks, 1965). Available iron-binding capacity was calculated as the difference between individual iron and total iron-binding capacity values.

\section{ANTIOXIDANT ACTIVITY}

Serum antioxidant activity was measured by the ability of serum to inhibit autoxidation in a standard biological preparation (Stocks et al., 1974a). The rate of autoxidation was measured by the generation of malonyldialdehyde (MDA) (Bidlack and Tappell, 1973). The biological preparation was a buffered ox brain homogenate. The antioxidant activity of different sera was expressed as the per cent inhibition of MDA generation.

\section{Results}

\section{COPPER AND CAERULOPLASMIN}

Levels of serum copper were significantly increased $(\mathbf{P}<0.001)$ in the main RA group as a whole compared with the control group. Although a strong sex difference was evident in both groups, serum copper levels being higher in women, the difference was also significant when males and females in the RA and control groups were compared separately. Serum copper in the group of women receiving oestrogenbased oral contraceptives was further significantly increased compared with the female controls $(\mathrm{P}<0.001)$.

Serum copper in the RA subgroup treated with intra-articular cortiscosteroids was significantly higher than that in the female control group but lower $(P<0.001)$ than that of female RA patients. Similarly, copper levels in the RA subgroup treated with sodium aurothiomalate were significantly higher than those in the controls but significantly lower than those in the main RA series. The lowest levels of copper and caeruloplasmin in RA patients were in the subgroup treated with D-penicillamine for 6 months. These results are summarised in Tables 1 and 2.

The raised serum copper in the main RA group was closely paralleled by an increase in caeruloplasmin concentration. There was a strong positive correlation between copper and caeruloplasmin in both the RA group $(r=0.843 ; P<0.001)$ and the control group $(r=0.867 ; P<0.001)$. Assuming that caeruloplasmin contains $0.32 \%$ its weight in copper, then in all the groups caeruloplasmin accounted for between $85 \%$ and $95 \%$ of the total
Table 1 Serum copper and caeruloplasmin levels (mean $\pm S D$ ) in male and female control subjects and in female controls receiving oestrogen-based oral contraceptives

\begin{tabular}{lrlll}
\hline & $n$ & $\begin{array}{l}\text { Copper } \\
(\mu \mathrm{mol} / \mathrm{l})\end{array}$ & $\begin{array}{l}\text { Caeruloplasmin } \\
(\mathrm{mg} / \mathrm{l})\end{array}$ \\
\hline All controls & 100 & $18 \cdot 5 \pm 3 \cdot 4$ & $314 \pm 77$ \\
$\begin{array}{l}\text { Female controls } \\
\text { Male controls }\end{array}$ & 60 & $19 \cdot 9 \pm 3 \cdot 9$ & $327 \pm 81$ \\
$\begin{array}{l}\text { Female controls receiving } \\
\begin{array}{l}\text { oestrogen-based oral } \\
\text { contraceptives }\end{array}\end{array}$ & 40 & $16 \cdot 4 \pm 2 \cdot 15$ & $285 \pm 69$ \\
\hline
\end{tabular}

Conversion: SI to traditional units-

Copper: $1 \mu \mathrm{mol} / 1 \approx 6 \cdot 37 \mu \mathrm{g} / 100 \mathrm{ml}$.

Table 2 Serum copper and caeruloplasmin levels (mean $\pm S D$ ) in the main group of rheumatoid patients treated with analgesic/anti-inflammatory drugs and in the rheumatoid subgroups treated with costericosteroids, aurothiomalate, and D-penicillamine

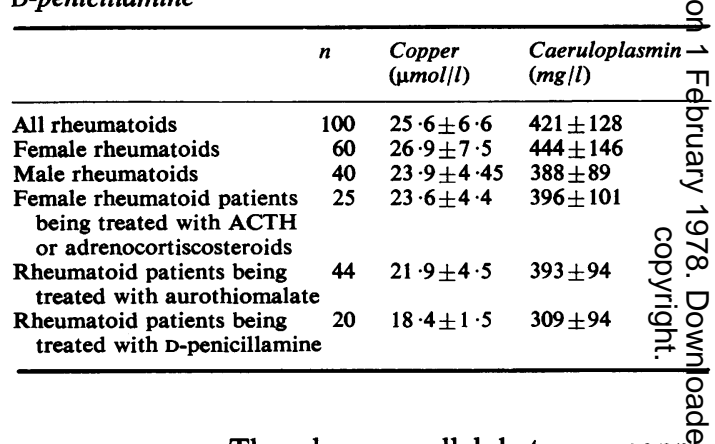

serum copper. The close parallel between copper and caeruloplasmin in both control and RA subjeģs persisted over a period of time, the two parametess showing no independent variation.

\section{SERUM ANTIOXIDANT ACTIVITY}

The mean serum antioxidant activity of the main $R$ group was significantly increased $(\mathrm{P}<0.001)$ co pared with both the control groups and the RA subgroup treated with sodium aurothiomalate. There was a strong sex difference, antioxidant activity of the female populations of both RA groups and the control group being higher than that of the corresponding male groups. There was $-\mathrm{a}$ strong positive correlation between antioxidapt activity and caeruloplasmin in all groups (Table 3 .

\section{SERUM IRON AND AVAILABLE}

IRON-BINDING CAPACITY

The mean serum iron levels in the main RA granp and in the RA patients treated with sodium auro thiomalate were both significantly reduced compared with the control group $(P<0.001)$. There was apparent sex difference in either series. The me्क्ष్n 
Table 3 Per cent serum antioxidant activity and correlation with caeruloplasmin in control subjects and in patients with rheumatoid arthritis

\begin{tabular}{|c|c|c|c|}
\hline & $n$ & $\begin{array}{l}\text { Antioxidant } \\
\text { activity } \\
\text { (mean } \pm S D)\end{array}$ & $\begin{array}{l}\text { Correlation } \\
\text { with } \\
\text { caeruloplasmin }\end{array}$ \\
\hline $\begin{array}{l}\text { Control group } \\
\text { Main rheumatoid group } \\
\text { Rheumatoid group treated } \\
\text { with aurothiomalate }\end{array}$ & $\begin{array}{r}100 \\
100 \\
44\end{array}$ & $\begin{array}{l}68 \cdot 4 \pm 10 \cdot 4 \\
81 \cdot 1 \pm 8 \cdot 5 \\
65 \cdot 7 \pm 8 \cdot 9\end{array}$ & $\begin{array}{l}\mathrm{r}=0.65 ; \mathrm{P}<0.001 \\
\mathrm{r}=0.58 ; \mathrm{P}<0.001 \\
\mathrm{r}=0.64 ; \mathrm{P}<0.001\end{array}$ \\
\hline
\end{tabular}

available iron-binding capacity was significantly increased $(P<0.001)$ in both RA groups compared with the control group (Table 4). The total ironbinding capacity showed no significant difference.

There was a strong inverse correlation between serum iron and serum copper in the control group, the main RA group and the RA subgroup treated with sodium aurothiomalate. The correlation was particularly pronounced in the main RA group.

\section{SERUM GOLD}

Serum gold levels in the RA patients treated with sodium aurothiomalate showed no significant correlation with any other parameter studied.

\section{Discussion}

This study clearly establishes that serum copper is significantly raised in rheumatoid disease in patients receiving analgestic/anti-inflammatory treatment. (None of the patients were wholly untreated.) Contrary to one recent report (Bajpayee, 1975), it is apparent that this is not simply a reflection of the unequal sex distribution of the disease. However, serum copper does rise into the 'rheumatoid range' in normal women taking oestrogen-based oral contraceptives. Our results also show that copper and caeruloplasmin rise in close parallel; and there is no significant difference in the copper/caeruloplasmin relation between controls and RA patients as a whole or between any of the RA subgroups of patients. It must be emphasised, however, that this does not exclude the presence in RA sera of an abnormal copper fraction-indeed considerable indirect evidence points in that direction (McMurray et al., 1975; Scudder, 1976). However, if such a fraction exists it is quantitatively insignificant. Serum copper was raised in almost all our patients in the 'main' rheumatoid group, but three different forms of therapy, namely D-penicillamine, sodium aurothiomalate, and corticosteroids, significantly reduced it.

While our study did not include an assessment of possible correlations of copper and caeruloplasmin with clinical parameters of disease activity in the RA subjects, a concurrent study (White et al., 1978) provides some evidence for a correlation between serum copper and the extent of erosive damage as seen in graded radiographs. Similarly increased levels of copper and caeruloplasmin were shown in the serum of psoriatic arthritis subjects with radiological erosions, but not in those without (Koskello et al., 1966).

Extensive correlations with other laboratory findings have not been made but serum copper was shown to correlate inversely and significantly with serum iron. It is not widely appreciated that such a correlation exists even in normal subjects, but it becomes much more significant in RA when serum iron falls and serum copper rises. This relation may be relevant to the aetiology and progress of rheumatoid anaemia. Although treatment with gold salts produces a fall in serum copper, serum gold levels do not correlate with either serum copper or serum iron. Preliminary findings suggest that such treatment has a marked effect on urinary copper excretion. Thus the mode of action of gold salts might be usefully re-examined in the wider context of trace-metal metabolism.

The highly significant correlation between serum caeruloplasmin and serum antioxidant activity supports the suggestion that this cuproprotein is the dominant variable governing serum antioxidant activity (Stocks et al., 1974b). The antioxidant activity of the serum may have considerable protective significance (Al-Timimi, 1977; Al-Timimi and Dormandy, 1977) especially in the presence of tissue damage or destruction. An increase in this activity may be an important component of the systemic inflammatory response.

Table 4 Serum iron, available iron-binding capacity, and the correlation between copper and iron in control subjects and in patients with rheumatoid arthritis (mean $\pm S D)$

\begin{tabular}{|c|c|c|c|c|}
\hline & $n$ & $\begin{array}{l}\text { Iron } \\
(\mu \mathrm{mol} / \mathrm{l})\end{array}$ & $\begin{array}{l}\text { Available iron- } \\
\text { binding capacity } \\
(\mu \mathrm{mol} \mathrm{Fe} / \mathrm{l})\end{array}$ & $\begin{array}{l}\text { Correlation between } \\
\text { copper and iron }\end{array}$ \\
\hline $\begin{array}{l}\text { Control group } \\
\text { Main rheumatoid group } \\
\text { Rheumatoid subgroup } \\
\text { treated with } \\
\text { aurothiomalate }\end{array}$ & $\begin{array}{r}100 \\
100 \\
44\end{array}$ & $\begin{array}{l}19 \cdot 3 \pm 6 \cdot 14 \\
11 \cdot 3 \pm 5 \cdot 75 \\
12 \cdot 5 \pm 5 \cdot 7\end{array}$ & $\begin{array}{l}46 \cdot 9 \pm 9 \cdot 1 \\
53 \cdot 7 \pm 17 \cdot 7 \\
49 \cdot 9 \pm 11 \cdot 7\end{array}$ & $\begin{array}{l}r=-0.366 ; P<0.001 \\
r=-0.488 ; P<0.001 \\
r=-0.350 ; P<0.001\end{array}$ \\
\hline
\end{tabular}


P.R.S. and T.L.D. gratefully acknowledge financial support from the Arthritis and Rheumatism Council for Research and the North East Thames Regional Health Authority. D.A.T. holds a postgraduate fellowship of the University of Baghdad.

\section{References}

Al-Timimi, D. J. (1977). Serum antioxidant activity. M.Phil. thesis, University of London.

Al-Timimi, D. J., and Dormandy, T. L. (1977). Inhibition of lipid autoxidation by human caeruloplasmin. Biochemical Journal, 168, 283-288.

Bajpayee, D. P. (1975). Significance of plasma copper and caeruloplasmin concentrations in rheumatoid arthritis. Annals of the Rheumatic Diseases, 34, 162-167.

Balazs, N. D. H., Pole, D. J., and Maserei, J. R. (1972). Determination of gold in body fluids by atomic absorption spectrophotometry. Clinica Chimica Acta, 40, 213-218.

Bidlack, W. R., and Tappell, A. L. (1973). Damage to microsomal membrane by lipid peroxidation. Lipids, 8 , 177-189.

Jayson, M. I. V., Davis, P., Whicher, J. T., and Walters, G. (1976). Serum copper and caeruloplasmin in ankylosing spondylitis, systemic sclerosis, and morphea. Annals of the Rheumatic Diseases, 35, 443-456.

Koskelo, P., Kekki, M., Virkkunem, M., Lasus, A., and Somer, T. (1966). Serum caeruloplasmin concentration in rheumatoid arthritis, ankylosing spondylitis, psoriasis and sarcoidosis. Acta Rheumatologica Scandinavica, 12, 261-272.
Lorber, A., Cutler, L. S., and Chang, C. C. (1968). Ser禺 copper levels in rheumatoid arthritis: relationship $\mathrm{g}$ elevated copper to protein alternations. Arthritis and Rheumatism, 11, 65-72.

McMurray, W., Martin, V. M., Scudder, P., Stocks, White, A. G., and Dormandy, T. L. (1975). Urinaß̧y copper excretion in rheumatoid arthritis. Annals of Rheumatic Diseases, 34, 340-352.

Mancini, G., Carbonara, A. O., and Heremans, J. F. (196 Immunochemical quantitation of antigens by single radiol immunodiffusion. Immunochemistry, 2, 235-242.

Scudder, P. R. (1976). Copper metabolism in rheumatoidd arthritis and related disorders. M.Phil. thesis, Universffy of London.

Sternlieb, I., Sandson, J. I., Morell, A. G., Korotkin, E., and Scheinberg, I. (1969). Non-caeruloplasmin copper d⿸丆口 rheumatoid arthritis. Arthritis and Rheumatism, $458-472$.

Stocks, J., Gutteridge, J. M. C., Sharp, R. J., and Dormanç T. L. (1974a). Assay using brain homogenate for measurifi the antioxidant activity of biological fluids. Clinical Science and Molecular Medicine, 47, 215-222.

Stocks, J., Gutteridge, J. M. C., Sharp, R. J., and Dormand\$ T. L. (1974b). The inhibition of lipid autoxidation human serum and its relation to serum proteins and -tocopherol. Clinical Science and Molecular Medicine, 47, 223-240.

Young, D. S., and Hicks, J. M. (1965). Method for t automatic determination of serum iron. Journal of Clinic Pathology, 18, 98-102.

White, A. G., Scudder, P., Dormandy, T. L., and Martif V. M. (1978). Rheumatism and Rehabilitation (in pres\& 